\title{
MEDIA ARRANGEMENT AS A FACTOR OF EXTERNAL INFLUENCE IN SOCIOLOGICAL REFLECTION: THEORETICAL ASPECT
}

\author{
Eduard Gugnin \\ Ph.D. in Sociology, Assistant Professor, \\ Assistant Professor at the Department of Social Work and Psychology, \\ First Vice-rector, "Zaporizhzhia Polytechnic" National University, Ukraine \\ e-mail: gugnined@gmail.com,orcid.org/0000-0002-6390-3691
}

\section{Summary}

The article provides a descriptive characteristics and classification of media support theories as a factor of external influence in conflict situations. In accordance with this goal, groups of neo-Marxist, poststructuralist, and socio-behavioral theories are identified. It is determined that the set of general theoretical postulates of the first group is, firstly, the postulate on the usurpation of media power by political and economic elites who are behind the financing and social patronage of cultural industries. Secondly, the postulate of information distortion, which consists in the fact that monopolizing classes are interested in forming a distorted picture of social reality. Thirdly, the postulate of forming a unified strategy of influence in the media space by power and economic elites, in respect of which media actors are considered mainly as repeaters of discourses.

It is determined that a set of general theoretical postulates of the second group is the recognition of linguistic (rhetorical and linguistic) factors of media support as the key ones. Secondly, the consideration of media actors as relatively independent producers of discourses, which have an independent meaning in the sphere of influence in comparison with social groups and institutions. Thirdly, the postulate regarding the positioning of supranational identities through language and the use of a specific (globalistic) vocabulary is of great importance for poststructuralism.

Keywords: external influence, media arrangement, neo-Marxism, post-structuralism, social behaviorism, mass media, media discourses, ideologies, favoritism, marginalization.

DOI https://doi.org/10.23856/4323

\section{Introduction}

Mass media are tools for achieving two basic states: social consensus and social discontent (dissensus). At the same time, both the first and second social states serve as the basis for legitimizing mass discontent, or vice versa, mass satisfaction about certain problems and restrictions.

One of the primary mechanisms of domination and colonization in certain societies is cognitive mechanisms such as categorization and stereotyping. At the media level, these mechanisms are applied through the spread of various prejudices that serve as the basis for the formation of social ideas. Thus, in media discourse, polar social ideas can be represented, reflecting the typical division into "we" and "they". At the same time, "we" in categorization can, for example, be associated with signs of progressiveness, development, social dynamism, whereas "they" - with backwardness, inertia, corruption. 
Such categorizations are sometimes part of the media discourse of Western and Euro-Atlantic societies in relation to Eastern societies. Therefore, Western societies in appropriate categorizations sometimes occupy the pole of a positive image, and Eastern societies - the pole of a negative image with corresponding characteristics (for example, primitive, dictatorial, violent and terrorist Islam, arabs or fundamentalism; hostile, secretive, insidious China in the American Media).

The role of media support in the implementation of various forms of external influence in modern conditions is difficult to underestimate. This is due to the fact that any act of external influence, as a rule, is preceded by media arrangement, which should prepare civil society for consolidated reactions with the state authorities. At the same time, the media become important and independent actors of such influence, and their activity, respectively, becomes the subject of sociological and interdisciplinary understanding in various theories. This article deals with the problem of constructing descriptive characteristics of such theories and their classification.

The purpose and objectives of the study. The purpose of the article is to give a descriptive characteristic and classification of media support theories as a factor of external influence in conflict situations. The objectives of the article, in accordance with the set goal, are: 1) construction of descriptive characteristics of media support theories; 2) construction of classification of media support theories; 3 ) determination of ideological mechanisms of media support in external influence.

Analysis of previous research on the selected topic. Media arrangements as a factor of external influence are part of mass communications, which became the subject of independent research at the beginning of the XX century. The methodological basis for media research was the understanding sociology of M. Weber, which justified the scope of mass media research, primarily in the aspect of connection of printed publications with various target audiences (Veber, 1990).

The evolution of theories took place in the direction of spreading theories of mass media influence on various components of mass consciousness and behavior. At the same time, there is reason to single out a group of theories that investigated, in particular, the possibilities and ways of media influence on people's attitudes, value orientations and behavior.

The genesis of theories of media influence on society includes two phases, namely, classical and post-classical (Dyakova, 1990, 20-60). This circumstance is primarily due to the difference in media research paradigms. At the classical stage, mainly logical and theoretical methods were used to study the influence of mass media on society and the main empirical methods were developed. At the present (postclassic) stage, researchers have made appropriate generalizations of media research materials.

The classical phase can, in turn, be divided into the interwar, post-war periods, the Cold War and bipolar world period, and the postmodern period.

Within the second phase (40-60s of the twentieth century), methodological skepticism spread, the discourse of which was initiated by P. Lazarsfeld and B. Berelson (Berelson, 1952). The researchers emphasized the importance of empirical methods of media research, in particular, content analysis, intent analysis and event analysis. In sociology, at this stage, within the framework of the phenomenological direction, the study of symbolic universes and conditions of relevance of everyday worlds takes place, which is presented in the works of A. Schutz (Shyuc, 2003).

As part of the third phase (the period of the Cold War and the bipolar world, 60-80-ies of the twentieth century), researchers moved on to generalize the results of empirical research, primarily to research on media policy and socio-cultural basics of media formation. In sociological discourse, the basics of these theories were formed by the works of P. Bourdieu in line 
with post-structuralist-neo-Marxist studies of symbolic violence, political fetishism, competence, monopolism based on delegation, etc. Significant for this period can also be considered the works of researchers of the Freud-Marxist direction (T. Adorno), that were devoted to the industries of culture and the formation of symbolic hegemony (Adorno, 1972).

The postmodern phase is characterized, first of all, by the lack of a unified paradigm for understanding the influence of mass media on public consciousness. At this stage, a number of theories have been developed, many of which are relevant for understanding the media support of external influence and all forms of interference. We are talking, in particular, about the theory of priming, the cultivation theory, the priority-setting theory, the uses and gratifications theory, the agenda-setting and news priority theories, etc. (A. Bandura, G. Gerbner, D. Domke, R. Morgan, R. Kaplan, J.-B. Thomson et al.). One of the most promising methods in modern conditions is the meta-analysis method, which allows you to generalize a large amount of empirical data and form a new generation of macrotheories.

\section{Presenting the main material}

Theories of media support of external influence, according to the criterion of peculiarities of the methodology used by the authors, can be divided into three groups: neo-Marxist, post-structuralist and socio-behaviorist (symbolic-interactionist).

A group of neo-Marxist theories. A set of common theoretical postulates of this group is, firstly, the postulate on the usurpation of media power by political and economic elites who are behind the financing and social patronage of cultural industries. Secondly, the postulate of information distortion, which consists in the fact that monopolizing classes are interested in forming a distorted picture of social reality. Thirdly, the postulate of forming a unified strategy of influence in the media space by power and economic elites, in respect of which media actors are considered mainly as repeaters of discourses.

The content of propaganda theory, or imposition theory, is the idea of controlling the media and military-administrative lobbies through economic power. At the same time, it is the latter that allows you to create social attachment to political decisions through the media. The theory of propaganda is based on the neo-Marxist methodology of A. Gramsci, P. Bourdieu, whose logic of studying the society allows the establishment of an indirect connection between the production of discourses, power and property.

The key focus of the theory is to understand the media as a lever of the state and economic elites, which allows both the former and the latter to make "the existing non-existent, and the non-existent to be existing". In fact, it is about getting into the space of discourse of only those topics that are beneficial to power circles. Mass media create favorable reference frames for these circles, from which the understanding of a particular society by another society begins (Herman, 1988, 25).

The analysis of media support is also implemented within the framework of the theories of media diplomacy as a new paradigm of foreign political influence. The very term "telediplomacy" was coined by R. Ammon. The author uses partly the methodology of the W. Beck's risk society, attributing telediplomacy to the external influence of society in the era of global risks (Ammon, 2001, 152).

The author justifies this by saying that a sign of TV diplomacy, unlike traditional diplomacy, is its unprecedented openness and transparency in relation to the media. This circumstance changes the paradigm of communication in the direction of creating new technologies for forming the agenda and the foreign and political influence of the media on foreign policy 
itself. Mass media through TV diplomacy acquire the status of an autonomous actor, that begins to determine both the strategy of foreign policy and individual foreign political decisions (Ammon, 2001, 152).

Thus, after the Cold War period, as a confrontation between the communist and capitalist worlds, there was a need for the image of a new enemy. Islamic fundamentalism has become such an enemy, which allegedly threatens the south pole of NATO. The relevant media and social networks carried out ideological and rhetorical preparation of social representations in the information space. Because of these widespread social beliefs, statements about Islamic fundamentalism as the main enemy of the West and the Euro-Atlantic have become plausible, if not universally accepted, in official discourse. In the cultural field, hysterical rhetoric was being whipped up against the Iron Curtain and the spread of Western-style freedom of speech. The political and military establishment has created waves in terms of focusing on terrorism, aggression, and fundamentalist threats.

Media concerns are considered within the framework of this theory as supporters of conservative political circles, which through media discourse justify their right to invade other countries. Thus, E. Herman and R. Peterson applied the theory of created consent to the crisis in Kosovo. This theory was based on neo-Marxist argumentation, which was dominated by indirect evidence. For lack of empiricism, planting theories often use guesswork about the possible causes of intervention and escalation of conflicts that precede military-humanitarian interventions (Herman, 2000).

The group of neo-Marxist theories can also include comparative political science studies, which, nevertheless, are important for the sociology of external influence. One of the comparative political science models was created by E. Herman. In constructing the model, the author proceeds from the typology of totalitarian, authoritarian, and liberal democratic political systems. At the same time, he analyzes a variant of the media policy strategy inherent in each type of political system (Jakobsen, 1996).

The theory focuses on a comparative analysis of the media policy of European and American societies. However, it lacks interest in Asian societies, which may also have their own media policies. The researcher identified four groups of factors for the success of media policy, namely: the presence of a developed media infrastructure; a significant volume of media recipients; media-active politicians and civil society, which influences media policy (Herman, 1988, 60-63).

A group of poststructuralist theories. The key postulates of poststructuralist theories are meaningfully focused, firstly, on the recognition of linguistic (rhetorical and linguistic) factors of media support as the key ones. Secondly, media actors are seen as relatively independent producers of discourses that have an independent meaning in the sphere of influence compared to social groups and institutions. Thirdly, the postulate regarding the positioning of supranational identities through language and the use of a specific (globalistic) vocabulary is of great importance for poststructuralism.

In this aspect, we are talking about media interventions of external influence, which become the subject of research for both general theories and empirical research. It is about agenda theory, framing theory, as well as empirical studies of the relations of political elites with the media. Examples of empirical research are the so-called "indexing theory" and the "consent theory" (Reese, 2001).

Empirical research in the framework of indexing theory proves the commitment of media actors to aggregating the ideas of the political establishment, which actually presents the media as a simple tool in the hands of military and administrative elites. The theory of indexing was 
tested on the material of 42 foreign political crises in the period from the beginning of the Cold War to the Kosovo crisis of 1999 (Zaller, 2000, 61-84).

The same theory has also been applied by other researchers to assess the US-Vietnam conflict. At the same time, it is said that in these repeated applications of indexing theory, the results obtained for the post-Cold War period were less convincing. This was due to the fact that there was a disappearance of geopolitical blocs and a decrease in the level of polarization of the world. That is why the results obtained by Zaller and Chiu regarding relations with media governments in the United States after the Cold War are more mixed.

The difference between the research results of the theory is attributed to the use of different content-analytical matrices. In some schemes, all political news (both positive and negative) were calculated. In other studies, only negative messages were counted. One part of the researchers conducted a content analysis of negative messages during interventions, including their placement, implementation, costs, and political support, while the other studied mostly negative news coverage of a policy in which its impact was denied. This methodological discussion reveals the weakness of the "indexing hypothesis" (Zaller, 2000, 61-84).

The analysis of media support is also implemented within the framework of theories of media diplomacy as a new paradigm of foreign political influence. The very term "telediplomacy" was coined by R. Ammon (Ammon, 2001).

Unlike traditional diplomacy, the author considers its unprecedented openness and transparency in relation to the media to be a sign of TV diplomacy. This circumstance changes the paradigm of communication in the direction of creating new technologies for forming the agenda and the foreign and political influence of the media on foreign policy itself. The media, through telediplomacy, acquire the status of an autonomous actor, that begins to determine both the strategy of foreign policy and individual foreign policy decisions (Ammon, 2001).

Shaw and Miller's poststructuralist theories are quite interesting. The authors applied correlation-factor analysis to study the Iraqi-Kurdish conflict. At the same time, the authors methodologically used the paradigm of "global civil society", in which communities without a clearly defined national and ethnic identity have ambitions to represent victims of national or international oppression and violence (Miller, 2002).

The authors focused on the policy-making process through rhetorical cliches. The author's methodology was to identify the relevant verbal figures and the accompanying sequence of political decisions with their coverage in the media. At the same time, both the relevant PR divisions of the government and the mass media used various means of putting pressure on their interlocutors in rhetorical cliches. Miller tested the "positioning hypothesis" by analyzing inter-institutional verbal communication between the media and government. The author's empirical material was video recordings and printed minutes of press conferences. It is about questions from journalists and answers from officials (Miller, 2002).

The authors' key statement about the media was attributing to them representative subjectivity and the characteristics of an institution that has a mandate to articulate the needs and interests of victims of violence and war. The authors also defended the circular model of media influence on politics, as well as vice versa, through public opinion. That is why the empirical basis for them was the secondary analysis of public opinion polls.

A group of socio-behavioral theories. In this group, preference is given to empirical studies of individual factors, mainly in the framework of quantitative studies. The latest behavioral research is focused on the topic of agency and cognitive certainty/uncertainty of political groups regarding the position of the media and the media support of a particular event by external influence. 
In the substitution theory, the subject of the author's analysis was military intervention, which the author evaluated, among other things, by the amount of attention paid in the media. His theory is based on quantitative data and is based on the reflection of political events in the media with concomitant changes in foreign policy strategies, both regarding the facts of US intervention in civil conflicts of other countries, and regarding specific methods of this intervention (economic sanctions, military interventions, media and cultural diplomacy, etc.) (Regan, 2000, 90-106).

In the theory of substitution of P. Regan, the importance of media coverage as a factor in the transformation of the corresponding strategies of external influence was revealed. However, the author made a number of methodological inaccuracies, deciding to narrow the field of research by print media and measuring purely extensive indicators of attention. The author actually equated the number of articles and reports to the level of significance of the event. That is why the reaction to the theory immediately became a series of critical comments that concerned its weaknesses.

The first weakness of the theory was the exaggerated importance of print media as a key source of information. After all, most people get information from the internet and from television, and not from the press. Secondly, the amount of media attention is not a mandatory indicator of the level of social significance of an event, since it is often just the opposite. Third, simple calculations of media attention are clearly insufficient. After all, in these volumes, various areas of lighting can be represented, positive, negative or neutral.

R. Jacobsen investigated a number of factors of humanitarian intervention as a technology of external influence, to which the author attributed legal factors (existing judicial or administrative resolutions on the facts); the presence/absence of national interests; assessment of risks and opportunities for successful implementation of the scenario of humanitarian intervention; the presence/absence of certain support groups within society. These factors were considered based on the Kuwait, North Iraq, Somali, Rwandan and Haitian crises.

The study of media arrangement as an auxiliary means of external influence was carried out within the framework of the Livingston-Eachus theory of agency. The authors created a three-component scheme of acting participation in humanitarian operations. Three groups of agents were identified in this model: decision-making agents; interference agents as for decision-making agents; and agenda-setting agents (including media and social media, both formal and informal). Accordingly, the authors also classified media effects into three groups: acceleration effects, interference effects, and agenda definition effects.

The researchers demonstrated manifestations of three groups of effects in three groups of actors in eight types of external intervention and influence: conventional wars, strategic and tactical deterrence campaigns, special operations and low-intensity conflicts, peacekeeping activities and peacekeeping operations combined with humanitarian operations and interventions. The empirical case for researchers was the peacekeeping interventions of NATO military contingents in Kosovo.

Among the behavioral studies, there is also P. Elliott's so-called theory of political uncertainty. The author correlates the level of influence of the media and the state of the politicum, stating that their influence will be the highest given the lowest certainty of the political elites' position on a conflict's situation and the necessary intervention. The researcher observes the highest influence of mass media also with specific content, which implies a critical attitude to the event and empathic coverage of it in the relevant media (Elliott, 1974, 249-268).

According to the logic of the author's reasoning, if the political community is confident in assessing the event and situation of the conflict, the level of media influence is most likely 
be low and insignificant. The analytical model was tested on the materials of the Bosnian and Kosovo conflicts.

\section{Conclusions}

To build a media support strategy for any conflict that involves or assumes the external influence of one society on another (through ordinary wars, humanitarian interventions, information special operations, etc.), three basic components are necessary: ideological and value, rhetorical, organizational and effective. All of them are combined in dominant discourses and can become the subject of research of three groups of theories, the authors of which prefer power and economic structures, the logosphere and language, political decisions and media actions. These aspects of external influence can become the subject of research in neo-Marxist, poststructuralist, and socio-behavioral theories. Despite all the differences in the discourses that accompany external influence, they are constructed from categorizations as separate elements.

Therefore, in the dominant discourse in the structure of categorization, there is a pole of well-being, peace, security, and a pole of poverty, randomness, and threat. The rich, intellectually developed, urban, information-competent are becoming the pole of calmness in favor of the poor, uneducated and underdeveloped, rural (provincial-peripheral) and agrarian-archaic. The leitmotif of pressure through media discourse is humanization within the framework of constructed social representations and dehumanization of others. Whoever these others are (ethnic minorities, migrants, gender groups, etc.), they are subject to negativization. To these groups, the media bring negative social ideas that express a state of dissatisfaction with them. In such circumstances, dividing the field of media categorization into images of higher and lower groups means using the ideology of open or hidden advantages both in politics and in the media. The ideology of superiority and inferiority, therefore, has a stable intellectual succession.

Social representations created by the media should both confirm the ideology and receive value legitimacy from it. At the same time, in any categorization, there are manifestations of double standards. All facts that are proposed to fit into its positive or negative poles must pass through the conveyor of double accounting: favoritism and discrimination. Group favoritism is accompanied by the formation of an image of a prestigious society, an example for worthy imitation of other societies. Its problems are either not considered in the media at all, or they are presented as transient and situational difficulties and must be solved.

Group discrimination is accompanied in the media by a negative agenda and news emphasis on negative events for those communities in respect of which certain forms of symbolic and cultural violence should be justified. The media form the main blocks of news, programs and films from facts or fantasies about real or alleged crimes of representatives of a hostile ethnic (national) community in the city center or in ethnically biased stories about drug addiction, mass riots and cultural deviations.

Discourses and narratives of parallel stories about hostile others there correspond to these vectors of marginalization of hostile others here. So, the dominant components of the media discourse that precedes certain colonization interventions against communities (societies, states) in modern conditions are crime, violence, terrorism and ethnic conflicts, fundamentalism, corruption and other forms of uncivilized backwardness.

Ideologies are the most powerful tools of colonization when identified with rationality and self-evidence. They justify the different values of certain social groups by appealing to humanity against violence, strengthening state security against terrorism, national equality 
against ethnic cleansing, genocide, relativism and tolerance against fundamentalism. Ideologies form a value superstructure for the implementation of any colonization projects. But in the modern world, these colonization projects are not limited to spreading among the elites and masses. They involve creating consensus in public discourses and public opinion through the mass media.

Media imperialism is becoming an ideology with discourses of attack as components of more powerful societies on less powerful societies, which are waging wars of meanings, market economies, political democracies with culturally marginalized societies. To do this, media factories use agendas, news headlines, articles, topics, images and narratives, which become a means of legitimizing and accustoming ethnic and social inequality on a macro-regional and global scale. This is facilitated by the focus on sensational topics presented in the media as part of the daily lives of those who are to be marginalized, repressed and further colonized. Such topics include corruption scandals, military coups, earthquakes, drug trafficking, clashes between mafia groups, inter-ethnic conflicts, and more.

\section{References}

Burde, P. (1993). Sociologiya politiki [Sociology of politics]. Moskva : Socio-Logos,. 336 s. [in Russian]

Burde, P. (2002). O televidenii i zhurnalistike [On television and journalism]. Moskva : Fond nauchnyh issledovanij "Pragmatika kultury", Institut eksperimentalnoj sociologii. 160 s. [in Russian]

Veber, M. (1990). Izbrannye proizvedeniya. [Selected works]. Moskva : "Progress”. 808 s. [in Russian]

Dyakova, E.G. (1999). Massovaya kommunikaciya i problema konstruirovaniya realnosti: Analiz osnovnyh teoreticheskih podhodov. [Mass communication and the problem of constructing reality: Analysis of basic theoretical approaches]. Ekaterinburg. 128 s. [in Russian]

Dyakova, E.G. (2001). Massovaya kommunikaciya: modeli vliyaniya. Kak formiruetsya "povestka dnya"? [Mass communication: models of influence. How is the "agenda" formed?]. Ekaterinburg : Izd-vo Gumanit. un-ta. 130 s. [in Russian]

Shyuc, A. (2003). Smyslovaya struktura povsednevnogo mira: ocherki po fenomenologicheskoj sociologii. [The semantic structure of the everyday world: essays on phenomenological sociology]. Moskva: Institut Fonda “Obshestvennoe mnenie”. 336 s. [in Russian]

Adorno T. \& Horkheimer M. (1972). The culture industry. Enlightment of mass deception. N.Y. : Herber and Herber.

Ammon, R. (2001). Global television and the shaping of world politics: CNN, telediplomacy, and foreign policy. Jefferson. N.C. : McFarland.

Bandura, A. (1994). Social cognitive theory of mass communication. Media effects: Advances in theory and research. Hillsdale. N.Y. : Erlbaum. Pp. 61-90.

Berelson, B. (1952). Content analysis in communication research. Glencoe : Free Press.

Domke, D., Shah, D.V. \& Wackman, D.B. (1998). Media priming effects: Accessibility, association, and activation. International journal of public opinion research. Pp. 51-74.

Elliott, P. (1974). Uses and gratifications research: A critique and a sociological alternative. The uses of mass communications: Current perspectives on ratifications research. Beverly Hills, C.A. : Sage, Pp. 249-268.

Gerbner G. (1976). Mass Media and Human Communication Theory. Sociology of Mass Communications. London. 
Gilboa, E. (2002). Global communication and foreign policy. Joumal of Communication. Pp. 731-748.

Graber, D. (2001). Processing politics: Leaming from television in the Internet age. Chicago : University of Chicago Press.

Graber, D. (2002). Mass media and American politics. Washington : Congressional Quarterly Press.

Herman, Edward S. \& Noam Chomsky. (1988). Manufacturing Consent. The Political Economy of the Mass Media. New York : Pantheon Books.

Herman, E., \& Peterson, D. (2000). CNN: Selling NATO's war globally. Degraded capabiiity: The media and the Kosovo crisis. London: Pluto Press. Pp. 111-122.

Jakobsen, P. (1996). National interest, humanitarianism or CNN: What triggers UN peace enforcement after the Cold War? Joumal of Peace Research. Pp. 205-215.

Jakobsen, P. (2000). Focus on the CNN effect misses the point: The real media impact on confiict management is invisible and indirect. Joumal of Peace Research. Pp. 131-143.

Kaplan, R. The Media and Medievalism. Retrieved from http://www.policyreview.org/dec04/ Kaplan.

Livingston, S., \& Eachus, T. (1995). Humanitarian crises and U.S. foreign policy: Somalia and the CNN effect reconsidered. Political Communication. Pp. 413-429.

Livingston, S. (1996). Suffering in silence: Media coverage of war and famine in the Sudan. From massacres to genocide: The media, public policy, and humanitarian crises. Cambridge, MA: World Peace Foundation. Pp. 68-89.

Livingston, S. (1997). Beyond the "CNN effect": The media-foreign policy dynamic. Politics and the press: The news media and their influences. Pp. 291-318.

Livingston, S., \& Eachus, T. (1999). Rwanda: U.S. policy and television coverage. The path of a genocide: The Rwanda crisis from Uganda to Zaire New Brunswick. NJ: Transaction. Pp. 209-228.

Livingston, S. (2000). Media coverage of the war: An empirical assessment. Kosovo and the challenge of humanitarian intervention: Selective indignation, collective action, and intemational citizenship. New York: United Nations University Press. Pp. 360-384.

Miller, D. (2002). Measuring media pressure on security policy decisionmaking in liberal states: The positioning hypothesis. Paper presented at the annual convention of the Intemational Studies Association. New Orleans.

Morgan M., Leggett S. \& Shanahan, J. (1999). Television and "family values": Was dan quayle right? Mass communication and society. Pp. 47-63.

Regan, P. (2000). Substituting policies during U.S. interventions in intemal conficts, a little of this, a little of that. Joumal of Conflict Resolution. Pp. 90-106.

Reese, S., Gandy, O., \& Grant, A. (2001). Framing public life. Mahwah. NJ: Erlbaum.

Shaw, M. (1996). Civil society and media in global crises: Representing distant violence. London : Pinter.

Shaw, D., \& Weaver, D. (1997). Communication and democracy: Exploring the intellectual frontiers in agenda-setting. Mahwah, NJ: Erlbaum.

Thompson J. B. (2003). The Media and Modernity. A social Theory of the Media. Oxford: Polity Press,

Zaller, J., \& Chiu, D. (2000). Govemment's little helper: U.S. press coverage of foreign policy crises, 1946-1999. Decisionmaking in a glass house. Pp. 61-84. 